\title{
As others see us...
}

After dinner speeches are very rarely remembered - for a variety of reasons - but there are exceptions, and those after the annual Harveian Oration at the Royal College of Physicicans (RCP) sometimes still resonate. For example, Lord Owen's warning to the RCP on the risks of getting too close to government - 'All governments start by offering to engage you, but they really wish to enfold you' - remains apposite (and still heeded by the RCP). This year, Lord Prior - Parliamentary Undersecretary for Health and Minister for NHS productivity (and one-time chairman of an NHS hospital trust) - offered a more direct warning to the profession, not on its relationships with authorities or regulators, but on its current standing. ${ }^{1}$

After a surprisingly frank aside on his personal view about Brexit - and warnings on the risks to both the NHS and UK universities were the movement of EU nationals or other foreigners to be limited - Lord Prior moved to discuss the standing of our profession, from the perspective of a critical friend. He described the shortcomings as he saw them, and the ways in which he felt doctors in the UK were failing to play their proper role in the NHS. Evidencing issues such as the low morale of doctors in training and the industrial disputes of the last year, he argued that we have become 'tribal... fragmented... dated... dysfunctional'. In respect to the running of the NHS as an institution, he saw us as on the touchline rather than on the playing field. He referenced the leitmotif of the Mayo Clinic, with physician leadership a key component in its architecture and its model of care, ${ }^{2}$ and contrasted this with what he saw as the paucity of quality clinical leadership in the UK (often selection by Buggin's term). Finally, he warned of the price that would likely be paid for not taking up the challenge of providing leadership - the loss of the esteem and trust in which the profession is held; we might indeed go the way of politicians and lose all the trust of the public.

Interestingly, discussion around the tables after the speech (necessarily an incomplete sample) did not demur from his main thesis, but put forward numerous possible explanations. Lord Prior dated the phenomenon to the introduction of the new consultant contract in 2002, which defined sessional commitments far more tightly than before, and many feel militated against the tradition of 'the extra mile'. Others felt the change went much further back, to the period of the Thatcher government and what is often described as its assault on the profession as a whole, not only doctors. There was surely a consensus that management pressures to corral doctors into increasingly defined sessional obligations and this, together with increases in service demand, discourages wider involvement in the organisation of services and encourages the physician to stick to his or her task - 'trained to look after patients, that's what I know I can do'. Other societal influences - including the entirely justifiable wish for a reasonable work-life balance were also seen to play a role; and certainly not least, increasing regulatory pressures.

In its recently published State of Medical education and Practice $2016{ }^{3}$ the General Medical Council (GMC) - the profession's main regulator - also has warnings, not only for the profession but for government, employers and regulators, including itself:

There is a state of unease within the medical profession across the UK that risks affecting patients as well as doctors.

To its credit, the GMC acknowledges the regulatory burden as one of the components leading to that unease, and outlines plans to modify that in the future, with initiatives to concentrate regulation in high-risk areas. But in addition, the GMC commits itself to promote the 'sort of professionalism that most of us would want to take for granted'.

Ten years ago the RCP debated medical professionalism at length, coming up with the definition as 'comprising a set of values, behaviours and relationships that underpin the trust the public has in doctors'. That RCP report foreshadowed many of the criticisms and issues that Lord Prior levels, notably on inadequate clinical leadership and the fragmentation of the medical voice. It is depressing that our critical friends feel we have not yet risen to face those challenges - to the cost of both us and our patients.

\section{References}

1 Smyth C. 1 Leaving Europe is a terrible mistake, minister tells doctors. London: The Times, 2016. www.thetimes.co.uk/article/leaving-europe-is-a-terriblemistake-minister-tells-doctors-ptkhf02f8 [Accessed 1 November 2016].

2 Mayo Clinic Model of Care. http://history.mayoclinic.org/impact/ mayo-clinic-model-of-care.php [Accessed 1 November 2016].

3 General Medical Council. The state of medical education and practice in the UK. London: GMC, 2016.

4 Working Party of the Royal College of Physicians. Doctors in society: medical professionalism in a changing world. Clin Med 2005;5(Suppl 1):S5-40.

Humphrey Hodgson

\section{Members of the editorial board}

Prof Humphrey Hodgson

Editor-in-chief

Dr Paul Grant

Editorial registra
Cono Arit

Statistical editor

Nick Cork

Medical student representative
Dr Na'eem Ahmed

Paul Belcher

Dr Rodger Charlton

Dr Tahseen Chowdhury

Dr Kate Evans

Prof Brian Hurwitz

Dr Angela King

Prof Philip MacCarthy
Prof Martin McKee

Dr Mehool Patel

Dr Gerrard Phillips

Dr Roby Rakhit

Prof Philip Smith

Dr Kevin Stewart

Prof Cameron Swift 